\title{
KEBIJAKAN PENDIDIKAN ISLAM DI INDONESIA
}

\author{
Samsuriadi $^{1}$ \\ ${ }^{* 1}$ Pendidikan Agama Islam Fakultas Agama Islam| Unismuh Makassar
}

\begin{abstract}
ABSTRAK
Metode yang digunakan dalam penelitian ini adalah metode deskriptif kualitatif. Penelitian deskriptif merupakan penelitian yang bertujuan menggambarkan kebijakan pendidikan di indonesia. Sedangkan sumbernya diambil dari beberapa buku-buku ilmiah yang diterbitkan dengan maksud dijadikan sumber referensi Adapun Tekhnik pengumpulan data dalam penelitian ini ialah Studi Kepustakaan, Wawancara dan Observasi. Hasil penelitian ini menunjukkan terkait kebijakan pendidikan islam diindonesia, Kebijakan di orde baru, kebijakan ditengah reformasi dan Pesantren di Tengah Pusaran Pendidikan Nasional
\end{abstract}

\section{Kata Kunci: Kebijakan, Pendidikan Islam}

\begin{abstract}
The method used in this research was descriptive qualitative method. Descriptive research was a study that aims to describe the education policy in Indonesia. While the source was taken from several scientific books published with the intention of being a reference source. The Technique of data collection in this study was Library Studies, Interviews and Observations. The results of this study indicate the related Islamic education policy in Indonesia, the policy in the new order, the policy amid the reformation and Pesantren in the Central rotation National Education
\end{abstract}

Keywords: The policy, Islamic Education 


\section{PENDAHULUAN}

Kata kebijakan merupakan bentuk turunan dari kata bijak yang memiliki awalan ke dan akhiran an. Di dalam KBBI (Kamus Lengkap Bahasa Indonesia), kata bijak memiliki arti selalu menggunakan akal budinya, mahir, pandai dan pandai bercakapcakap. Dalam bahasa Inggris, kebijakan diartikan sebagai policy yang berarti plan of action (rencana kegiatan) atau statemen of aims (pernyataan yang diarahkan). Adapun yang dimaksud kebijakan adalah pernyataan cita-cita, tujuan, prinsip, atau maksud sebagai garis pedoman untuk mencapai sasaran, garis haluan. Di dalam buku Ramayulis dan Samsul Nizar di jelaskan bahwa Pendidikan berasal dari bahasa Yunani, yaitu paedagogie yang berarti bimbingan yang di peruntukkan untuk anak. Istilah ini kemudian diterjemahkan ke dalam bahasa Inggris dengan education yang berarti pengembangan atau bimbingan. Dalam bahasa Arab, istilah ini sering diterjemahkan dengan tarbiyah yang berarti pendidikan.

Pengertian kebijakan pendidikan sebagaimana dikutip oleh Ali Imran dari Carter V. Good bahwa kebijakan pendidikan adalah suatu pertimbangan yang didasarkan atas sistem nilai dan beberapa penilaian terhadap faktorfaktor yang bersifat situasional. Pertimbangan tersebut dijadikan sebagai dasar untuk mengoperasikan pendidikan yang bersifat melembaga serta merupakan perencanaan umum yang dijadikan sebagai pedoman untuk mengambil keputusan agar tujuan yang bersifat melembaga dapat tercapai.

Pendidikan merupakan hal yang sangat penting, sebab biasanya kualitas kecerdasan manusia dilihat dari seberapa besar kemauan seseorang tersebut mengenyam pendidikan. Tidak hanya itu dengan adanya pendidikan, manusia juga dapat mencapai pemenuhan kebutuhan hidupnya dengan cara bekerja. Bukan hal yang istimewa lagi jika banyak orang berlomba-lomba untuk mengenyam pendidikan setinggi-tingginya.

Pemerintah juga tidak main-main dalam menggalakkan pendidikan, terbukti dari adanya salah satu peraturan yang mengatur tentang pendidikan. Peraturan tersebut tertuang dalam UUD 1945 pasal 31 ayat (1) disebutkan bahwa : Tap-tiap warga negara berhak mendapatkan pengajaran; ayat (2) Pemerintah mengusahakan dan menyelenggarakan satu sistem pengajaran nasional yang diatur dengan undang-undang. Dari penjelasan pasal ini pemerintah memberikan petunjuk bahwa pemerintah mendapatkan amanat untuk menjamin hak-hak warga negara dalam mendapatkan layanan pendidikan, tak terkecuali pendidikan Islam itu sendiri. selain itu pemerintah juga berkewajiban untuk menyelenggarakan satu sistem pengajaran nasional.

\section{METODE PENELITIAN}

Metode yang digunakan dalam penelitian ini adalah metode deskriptif 
kualitatif. Penelitian deskriptif merupakan penelitian yang bertujuan menggambarkan kebijakan pendidikan di indonesia. Sedangkan sumbernya diambil dari beberapa buku-buku ilmiah yang diterbitkan dengan maksud dijadikan sumber referensi Adapun Tekhnik pengumpulan data dalam penelitian ini ialah Studi Kepustakaan, Wawancara dan Observasi.

\section{HASIL DAN PEMBAHASAN PENELITIAN}

Urusan agama yang ada sebelum kemerdekaan ditangani oleh kantor agama yang pada masa penjajahan Belanda bernama resmi Kantoor voor Inlandshe Zaken kemudian pada penjajahan Jepang bernama Shumuka setelah Indonesia mengganti nama Kementrian Agama dan diresmikan pada tanggal 3 Januari 1946. Kementrian Agama juga mengurusi bidang pendidikan yang berhubungan dengan agama. BP KNIP menyampaikan usulan dan rencana pengembangan kelembagaan agama Islam, baik di lingkungan pesantren maupun madrasah kepada Kementerian Pendidikan, Pengajaran, dan Kebudayaan (PP\&K). Di antara usulan itu adalah perbaikan kualitas pesantren dan madrasah, modernisasi pengajarannya dan diberikan bantuan. Setelah Kementerian Agama dibentuk dengan K.H. Wahid Ha-syim sebagai Menteri Agama, perhatian terhadap pesantren semakin bertambah. Siswa, kyai, dan pesantren semakin bertambah banyak dan pada akhir periode Orde Baru jumlah pesantren tercatat 8.376 buah.

\section{Kebijakan Pendidikan Islam di} Nusantara Masa Orde Baru

Pada tahun 1967 Menteri Agama mengeluarkan kebijakan untuk menegerikan sejumlah madrasah dalam semua tingkatan dari tingkat Ibtidaiyah sampai Aliyah. Sejumlah madrasah menjadi negeri dengan rincian, 358 Madrasah Ibtidaiyah Negeri (MIN), 182 Madrasah Tsanawiyah Negeri (MTsN) dan 42 Madrasah Aliyah Agama Islam Negeri (MAAIN). Dengan memberikan status negeri, tanggung jawab pengelolaan menjadi beban pemerintah, tetapi pengaturan dan control atas madrasah-madrasah itu menjadi lebih efektif.

Dan pada dua tahun berikutnya Kepres ini dipertegas dengan Instruksi Presiden No. 15 tahun 1974 yang mengatur realisasinya. Kedua kebijakan ini menimbulkan reaksi umat Islam. Diantaranya adalah Musyawarah Kerja Majelis Pertimbangan Pendidikan dan Pengajaran Agama (MP3A). Lembaga ini meyakinkan bahwa madrasah adalah lembaga pendidikan yang memberikan sumbangan yang cukup berarti dalam pembangunan nasional. Menyinggung tentang madrasah itu, MP3A menegaskan bahwa "yang paling tepat diserahi tanggung jawab itu ialah Departemen Agama, sebab Menteri Agamalah yang lebih tahu tentang seluk 
beluk pendidikan agama bukan Menteri $\mathrm{P} \& \mathrm{~K}$ atau menteri-menteri lain.

Dengan memperhatikan aspirasi tersebut, pemerintah indonesia dalam hal ini kementrian Agama RI melakukan pembinaan mutu pendidikan madrasah secara terus-menerus. Pada tahun 1975 dikeluarkan Surat Keputusan Bersama Tiga Menteri mengenai "Peningkatan mutu pendidikan madrasah". Dan dilanjutkan dengan Presiden mengeluarkan Petunjuk Pelaksanaan Kepres No. 34 tahun 1972 dan Inpres No. 15 tahun 1974 yang isinya:

a. Pembinaan pendidikan umum adalah tanggung jawab Menteri Pendidikan dan Kebudayaan, sedang tanggung jawab pendidikan agama menjadi tanggung jawab Menteri Agama.

b. Untuk pelaksanaan Kepres No. 34 tahun 1972 dan Inpres No. 15 tahun 1974 dengan sebaik-baiknya perlu ada kerjasama antara Departemen P\&K, Departemen Dalam Negeri dan Departemen Agama

Posisi madrasah ini dipertegas kembali dalam UUSPN No. 2 tahun 1989, bab IV pasal 11, ayat 6 tentang pendidikan keagamaan, yang kemudian dijabarkan dalam peraturan pemerintah ataupun keputusan menteri, bahwa MI, MTs, dan MA masing-masing termasuk SD, SLTP, SMU yang berciri khas agama Islam dan diselenggarakan oleh Kementerian Agama. Tanggung jawab atas pengelolaan madrasah dilimpahkan oleh Menteri Pendidikan kepada Menteri
Agama, dan siswa berhak memperoleh pendidikan agama sesuai dengan agama yang dianutnya. Apabila dalam satu kelas di suatu sekolah terdapat sekurangkurangnya 10 (sepuluh) orang siswa yang memeluk agama tertentu, pendidikan agama siswa yang bersangkutan wajib diberikan di kelas tersebut, sementara bagi siswa yang tidak memeluk agama yang sedang diajarkan pada saat berlangsungnya pelajaran agama di kelas itu, diberi kebebasan. Kurikulum dan bahan kajian yang diberikan di madrasah minimal sama dengan sekolah, di samping bahan kajian lain yang dinerikan pada madrasah tersebut. Dengan keluarnya petunjuk pelaksanaan tersebut, ketegangan antara pendidikan agama dan pendidikan nasional memang dapat diatasi. Petunjuk pelaksanaan itu mengandung perbedaan yang cukup mendasar dengan Kepres dan Inpres tersebut. Disitu ditegaskan bahwa hak dan tanggung jawab pengelolaan pendidikan agama tetap berada pada Departemen Agama.

\section{Kebijakan Pendidikan Islam di}

\section{Nusantara Masa Reformasi}

Pada tahun 1994, kebijakan kurikulum pendidikan agama ditempatkan di seluruh jenjang pendidikan, menjadi mata pelajaran wajib sejak SD sampai Perguruan Tinggi. Pada jenjang pendidikan SD, terdapat 9 mata pelajaran, termasuk pendidikan agama. Di SMP struktur 
kurikulumnya juga sama, dimana menyebutkan bahwa pendidikan agama pendidikan agama masuk dalam adalah hak setiap peserta didik. "Setiap kelompok program pendidikan umum. peserta didik pada setiap satuan Demikian halnya di tingkatan SMU, pendidikan berhak mendapatkan dimana pendidikan agama masuk dalam pendidikan agama sesuai dengan agama kelompok program pengajaran umum bersama Pendidikan Pancasila dan Kewarganegaraan, Bahasa dan Sastra Indonesia, Sejarah Nasional dan Sejarah Umum. Bahasa Inggris, Pendidikan Jasmani dan Kesehatan, Matematika, IPA (Fisika, Biologi, Kimia), IPS (Ekonomi, Sosiologi, Geografi) dan Pendidikan Seni.

Dari sudut pendidikan agama, Kurikulum 1994, hanyalah penyempurnaan dan perubahanperubahan yang tidak mempengaruhi jumlah jam pelajaran dan karakter pendidikan keagamaan siswa, sebagaimana tahun-tahun sebelumnya. Saat rezim Orde Soeharto tumbang di tahun 1998, pendidikan di Indonesia, masih menggunakan UU Pendidikan tahun 1989, dan kuriklum 1994. Tumbangnya rezim Soeharto menggulirkan gagasan reformasi, yang salah satu agendanya adalah perubahan dan pembaruan dalam bidang pendidikan, sebagaimana yang menjadi tema kritik para pemerhati pendidikan dan diharapkan oleh banyak pihak.

Selanjutnya pada tahun 2003 ditetapkan Undang-Undang Sistem Pendidikan Nasional yang selanjutnya disebut dengan UU Sisdiknas No. 20 tahun 2003. Dalam UU Sisdiknas No. 20 tahun 2003 ini pasal yang diperdebatkan dengan tegang adalah pasal 12 yang pendidikan yang seagama," (Pasal 12 ayat a). Dalam bagian penjelasan diterangkan pula bahwa pendidik atau guru agama yang seagama dengan peserta didik difasilitasi atau disediakan oleh pemerintah atau pemerintah daerah sesuai dengan kebutuhan satuan pendidikan sebagaimana diatur dalam pasal 41 ayat 3 .

UU ini juga sekaligus "mengubur" bagian dari UU No. 2/1989 dan Peraturan Pemerintah, No. 29/1990, tentang tidak wajibnya sekolah dengan latar belakang agama tertentu (misalnya Islam) mengajarkan pendidikan agama yang dianut siswa (misalnya pelajaran agama Katolik untuk siswa yang beragama Katolik). UU Sisdiknas 2003 mewajibkan sekolah/ Yayasan Islam untuk mengajarkan pendidikan Katolik untuk siswa yang menganut agama Katolik. UU Sistem Pendidikan Nasional No. 20 tahun 2003 inilah yang menjadi pijakan hukum dan konstitusional bagi penyelenggaraan pendidikan agama di sekolah-sekolah, baik negeri maupun swasta. Pada pasal 37 ayat (1) disebutkan bahwa 'kurikulum pendidikan dasar dan menengah wajib memuat pendidikan agama, pendidikan kewarganegaraan, bahasa, matematika, ilmu pengetahuan sosial, seni dan budaya, pendidikan jasmani dan 
olahraga, keterampilan/kejuruan dan muatan lokal. Dalam penjelasan atas pasal $37 \quad$ ayat 1 ini ditegaskan, "pendidikan agama dimaksudkan untuk membentuk peserta didik menjadi manusia yang beriman dan bertakwa kepada Tuhan Yang Maha Esa serta berakhlak mulia”. Pelaksanaan pendidikan agama di sekolah umum, juga diatur dalam undang-undang baik yang berkaitan dengan sarana dan prasarana pendidikan, biaya pendidikan, tenaga pengajar, kurikulum dan komponen pendidikan lainnya.

Perjalanan kebijakan pendidikan Indonesia belum berakhir, pada tahun 2004 pemerintah menetapkan Kurikulum Berbasis Kompetensi (KBK). Kehadiran Kurikulum berbasis kompetensi pada mulanya menumbuhkan harapan akan memberi keuntungan bagi peserta didik karena dianggap sebagai penyempurnaan dari metode Cara belajar siswa Aktif (CBSA). Namun dari sisi mental maupun kapasistas guru tampaknya sangat berat untuk memenuhi tuntutan ini. Pemerintah juga sangat kewalahan secara konseptual, ketika pemerintah bersikeras dengan pemberlakukan Ujian Nasional, sehingga KBK segera diganti dan disempurnakan dengan Kurikulum Tingkat Satuan Pendidikan (KTSP).

Kementerian Agama RI di tahun 2010-2014 menetapkan 5 kebijakan yaitu :

a. peningkatan kualitas kehidupan beragama

b. peningkatan kualitas kerukunan umat beragama; c. peningkatan kualitas raudhatul athfal, madrasah, perguruan tinggi agama, pendidikan agama, dan pendidikan keagamaan;

d. peningkatan kualitas penyelenggaraan ibadah haji, dan;

e. perwujudan tata kelola kepemerintahan yang bersih dan berwibawa.

\section{Pesantren di Tengah Pusaran \\ Pendidikan Nasional}

Kata pesantren yang berasal dari kata santri dengan mendapatkan awalan pe- dan akhiran -an. Kata tersebut mengandung arti asrama tempat tinggal santri atau tempat murid-murid belajar mengaji dan sebagainya. Istilah santri berasal dari bahasa Tamil yang berarti guru ngaji. Sumber yang lain menyebutkan bahwa kata itu berasal dari bahasa Inda Chasti dari akar kata Shastra yang berarti buku-buku suci, buku-buku agama atau buku-buku tentang ilmu pengetahuan.

Kata pesantren sering digunakan dalam bahasa sehari-hari dengan tambahan kata "pondok" menjadi "pondok pesantren". Ditinjau dari segi bahasa, kata pondok dengan kata pesantren tidak ada perbedaan yang mendasar diantara keduanya karena kata pondok adalah berasal dari bahsa Arab funduq yang artinya hotel dan pesantren. Dalam pemahaman masyarakat Indonesia dapat diartikan sebagai tempat berlangsungnya suatu pendidikan agama Islam yang telah 
melembaga sejak zaman dahulu. Jadi pada hakikatnya pondok pesantren merupakan lembaga pendidikan agama Islam.

$$
\text { Dalam buku yang }
$$

berjudul Pedoman Pembinaan Pondok Pesantren yangdikeluarkan oleh

Departemen Agama halaman 9 mendifinisikan pondok pesantren sebagai :

"Lembaga pendidikan dan pengajaran agama Islam yang pada umumnya pendidikan dan pengajaran tersebut diberikan dengan cara nonklasikal dimana seorang kyai mengajar santri-santri berdasarkan kitab-kitab yang ditulis dalam bahasa Arab oleh ulama-ulama besar sejak abad pertengahan sedang para santri biasanya tinggal dalam pondok dalam pesantren tersebut."

Sementara itu Muki Ali dalam makalahnya yang berjudul dinamisasi dan hakikat pondok pesantren disampaikan pada musyawarah lokakarya intensifikasi pengembangan pondok pesantren mengidentifikasi bahwa pondok pesantren mempunyai ciri-ciri adanya kyai yang mengajar dan mendidik. Santri yang belajar dari kyai, masjid tempat untuk menyelenggarakan pendidikan,shalat berjamaah dan sebagainya, pondok tempat tinggal para santri.

Dalam undang-undang No. 20 Tahun 2003 tentang Sistim Pendidikan Nasional ditetapkan, pedidikan nasional berfungsi mengembangkan kemampuan dan membentuk watak serta peradaban bangsa yang bermartabat dalam rangka mencerdaskan kehidupan bangsa, bertujuan berkembangnya potensi peserta didik agar menjadi manusia yang beriman yang bertaqwa kepada Tuhan Yang Maha Esa, berakhlaq mulia, sehat, berilmu,cakap, kreatif, mandiri,dan menjadi warga negara yang demokratis serta bertanggung jawab.

Ketentuan diatas menempatkan pendidikan agama pada posisi yang amat strategis dalam upaya mencapai tujuan pendidikan nasional yang diharapkan. Pondok pesantren merupakan bagian pendidikan keagamaan yang secara historis telah mampu membuktikan secara kongkrit dalam membentuk manusia indonesia yang beriman dan bertaqwa kepada Tuhan Yang Maha Esa. Dengan demikian, secara filosofis maupun historis dan secara yuridis, pondok pesantren pun dengan tegas tercakup dalam ketentuan-ketentuan yang ada dalam Undang-Undang tentang Sistim Pendidikan Nasional.

Posisi strategis pondok pesantren dan madrasah diniyah dalam sistim pendidikan nasional itu juga memberikan peranan yang penting dalam pelaksanaan sistim pendidikan nasional, yaitu :

1. Peranan Instrumental. Upaya pendidikan secara nasional, tak pelak lagi memerlukan sarana-sarana sebagai media untuk mengejawantahkan tujuan-tujuannya. Sarana-sarana itu, selain dibentuk 
secara formal seperti halnya gedung sekolah, juga dibentuk secara informal yang tumbuh dan berkembang di Indonesia pada umumnya merupkan kreasi murni para kyai-ulama dalam usaha menciptakan sarana pendidikan. Dalam tataran inilah, peranan pondok pesantren sebagai alat atau instrumen pendidikan nasional.

2. Peranan Keagamaan. Pendidikan pondok pesantren pada hakikatnya tumbuh dan berkembang sepenuhnya berdasarkan motivasi agama. Lembaga ini dikembangkan untuk mengefektifkan usaha penyiaran dan pengamalan ajaran-ajaran agama. Dalam pelaksanaanya, pendidikan pondok pesantren melakukan proses pembinaan pengetahuan, sikap dan kecakapan yang menyangkut segi keagamaan. Tujuan intinya adalah mengusahakan terbentuknya manusia berbudi luhur (al-akhlaqul kariamah) dengan pengalaman keagamaan yang konsisten (istiqomah). Pendidikan Nasional sendiri bertujuan, untuk menciptakan manusia yang beriman, bertaqwa dan berakhlaq mulia. Untuk kepentingan ini pendidikan agama dikembangkan secara terpadu, baik melalui sekolah umum maupun madrasah.

3. Peranan Memobilisasi Masyarakat. Dalam kenyataannya, usaha-usaha pendidikan nasional secara formal belum mampu menampung seluruh aktifitas pendidikan masyarakat Indonesia, di samping karena ada sebagian masyarakat yang kurang kesadarannya akan pentingnya pendidikan (sekolah), juga karena memang sarananya masih sangat terbatas, terutama di pedesaan. Bagi sebagian masyarakat masih terdapat kecenderungan yang memberikan kepercayaan pendidikan putraputrinya hanya kepada pondok pesantren.

4. Peranan Pembinaan Mental dan Ketrampilan. Dalam sistim pendidikan Nasional, tujuannya adalah menciptakan manusia Indonesia yang memiliki kepribadian yang sehat, berilmu, cakap, kreatif, mandiri, dan menjadi warga negara yang demokratis serta bertanggung jawab. Pendidikan di pondok pesantren diselenggarakan tidak hanya pada pendidikan keagamaan semata, melainkan juga dikembangkan pembinaan mental dan sikap para santri untuk hidup mandiri, meningkatkan keterampilan dan berjiwa entrepreneurship. Karena di pondok pesantren dikembangkan juga unit usaha atau pembinaan yang diselenggarakan dalam memenuhi tuntutan zaman dimana mereka, para santri, setelah lulus dan keluar pondok pesantren memiliki sesuatu keterampilan tertentu yang dapat dikembangkan secara mandiri sebagai bekal hidupnya.

Peranan pendidikan pesantren dalam pelaksanaan pendidikan nasional dapat lihat dalam kaitannya sebagai sub- 
sistem pendidikan nasional. Pesantren merupakan lembaga yang berfungsi melaksanakan pendidikan berdasarkan arah dan tujuan yang telah ditentukan. Dengan fungsi khusus yang dibawakan oleh sistim pendidikan ini, pendidikan nasional akan menunjukkan dinamikanya secara mantap untuk kepentingan ini.

Walaupun peranan penting yang diberikan pondok pesantren terhadap pelaksanaan pendidikan bagi rakyat Indonesia, tetapi perhatian negara terhadap pondok pesantren masih kurang baik, apalagi pondok pesantren yang tidak menyesuaikan diri dengan jenjang dan sistim pendidikan formal. Rendahnya perhatian negara terhadap pondok pesantren tampak dalam ketidak jelasan kedudukan dan pengakuan terhadap lulusan pondok pesantren. Santri yang telah tamat pendidikan di pondok pesantren tidak memiliki civil efect sebagaimana tamantan pendidikan formal, padahal dari segi kualitas penguasaan materi yang dipelajari lulusan pesantren pun tidak kalah dengan siswa yang mengikuti pendidikan formal. Bahkan mungkin dalam aspek-aspek tertentu lulusan pesantren memiliki keunggulankeunggulan yang tidak dimiliki oleh lulusan pendidikan formal, misalnya, kuatnya sikap mandiri, ketaatannya dalam beribadah, serta akhlaq yang lebih terjamin.

Pondok pesantren masuk kedalam sistim pendidikan nasional berarti seluruh yang dilakukan oleh pondok pesantren yang jelasjelas melaksanaka pendidikan secara komprehensif dan holistik untuk kepentingan mencerdaskan kehidupan bangsa namun belum masuk hitungan dalam substansi pelayanan /pembinaan yang tergambar dalam rendahnya alokasi anggaran dan bantuan kependidikan lainnya bagi pondok pesantren, seperti pembiayaan penyiapan saran dan prasarana pembelajaran, pembiayaan proses pembelajaran, tenaga kependidikan dan pengelolaan.

\section{KESIMPULAN}

Pendidikan Islam sudah ada sejak dahualu bahkan sebelum bangsa Eropa termasuk Belanda menginjakkan kaki di negara tercinta ini. Pendidikan Islam sudah berkembang di Indonesia seiring dengan perkembangan agama islam di negara kita. Hanya saja, yang terjadi dengan pendidikan islam di negara kita adalah belum adanya lembaga formal yang menampung murid-murid dalam pelaksanaan pendidikan islam. Begitu pula dengan kebijakan-kebijakan yang diperuntukkan untuk pendidikan Islam yang mana bersifat dinamis.

\section{DAFTAR PUSTAKA}

Abd.

Rachman Assagaf, Internationalisasi Pendidikan, Sketsa Perbandingan Pendidikan di Negara-Negara Islam dan Barat.Yogyakarta: Gama Media, 2003. 
Abuddin Nata, Kapita Selekta Pendidikan Islam . Bandung: Angkasa, 2003.

Ali Imron, Kebijaksanaan Pendidikan di Indonesia: Proses, Produk, dan Masa Depannya,Ed. I, Cet. II ,Jakarta: Bumi Aksara, 2002.

Budiono, Kamus Lengkap Bahasa Indonesia(Surabaya: Karya Agung, 2005.

Departemen Agama R I, Pondok Pesantren dan Madrasah Diniyah Pertumbuhan dan Perkembangannya Jakarta: DIrektorat Jenderal Kelembagaan Agama Islam,2003.

Engku. Zubaidah, Sejarah Pendidikan Islam (Bandung: PT Remaja Rosdakarya.

Hasbullah, Dasar-dasar Ilmu Pendidikan, Edisi Revisi, Cet. VI ,Jakarta: Rajagrafindo Persada, 2008.

Hasbullah, Sejarah Pendidikan Islam di Indonesia, Lintas Sejarah pertumbuhan dan Perkembangan ,Jakarta : PT. Raja Grafindo Persada,1999.

Iskandar Engku,Siti Zubaidah, Sejarah Pendidikan Islam .Bandung: PT Remaja Rosdakarya.

Lihat Oxford University, Oxford Learner's Pocket Dictionary, Edisi II, Cet V(Oxford: Oxford University Press, 1995.

Lihat Tim Penyusun Kamus Pusat Bahasa, Kamus Bahasa Indonesia .Jakarta: Pusat Bahasa Dep. Diknas,2008. 